\title{
ADAPTIVE CONTROL OF THE DRIVE SYSTEM WITH ELASTIC COUPLING USING FUZZY KALMAN FILTER WITH DYNAMIC ADAPTATION OF SELECTED COEFFICIENTS
}

\section{STEROWANIE ADAPTACYJNE UKŁADU NAPĘDOWEGO Z POŁĄCZENIEM SPRĘŻYSTYM WYKORZYSTUJĄCE ROZMYTY FILTR KALMANA Z DYNAMICZNĄ ADAPTACJĄ WYBRANYCH WSPÓŁCZYNNIKÓW*}

\begin{abstract}
In the paper issues related to damping of torsional vibrations in electric drive systems with elastic joint with changeable inertia of the load machine using an adaptive control structure are presented. In order to state variables estimation of a drive system, the extended Kalman filter with a dynamic adaptation of selected coefficients has been applied. Adaptation of selected coefficients of the Kalman filter's covariance matrix ensures an improvement of the state variables and parameter estimation quality of the considered drive system with changeable inertia. The element implementing the adaptation is a fuzzy system, whose input signals are a current estimated value of a time constant of the load machine and a processed signal of an absolute value of difference between the electromagnetic and shaft torques. Theoretical considerations and simulation studies have been verified by tests with laboratory set-up.
\end{abstract}

Keywords: two-mass system, vibrations damping, estimation, Kalman filter.

\begin{abstract}
$W$ artykule przedstawiono zagadnienia zwiazane z thumieniem drgań skrętnych w elektrycznych ukladach napędowych z połaczeniem sprężystym o zmiennym momencie bezwładności maszyny roboczej poprzez zastosowanie struktury sterowania adaptacyjnego. W celu odtwarzania zmiennych stanu rozpatrywanego uktadu wykorzystano zmodyfikowany algorytm rozszerzonego filtru Kalmana z dynamiczna adaptacja wybranych współczynników. Adaptacja wspótczynników macierzy kowariancji zapewnia poprawę jakości estymacji zmiennych stanu i parametru układu w obecności zmiennego momentu bezwładności. Elementem realizującym wspomniana adaptacje jest system rozmyty, którego sygnałami wejściowymi sa aktualna estymowana wartość stałej czasowej maszyny roboczej oraz przetworzony sygnat modulu różnicy pomiędzy momentami elektromagnetycznym i skrętnym. Rozważania teoretyczne i badania symulacyjne zostały zweryfikowane przez testy na stanowisku rzeczywistym.
\end{abstract}

Stowa kluczowe: układ dwumasowy, thumienie drgań, estymacja, filtr Kalmana.

\section{Introduction}

Expectations towards modern drive systems are mainly focused on the precise control of speed and/or position. Examples of the drive systems which have to meet such requirements are servo drives and manipulators of industrial robots [11]. In many mechatronic drive applications there are nonlinear phenomena, changeability of system parameters during operation or oscillations of the electromechanical state variables. In the case of an application of simplified approach for modelling of the drive systems as the one-mass system and the lack of control structure adaptation to changeable operation conditions, these phenomena contribute to the improper operation of the drive system. One of the main causes of the electromechanical state variables oscillations of the drive systems is a finite stiffness of a coupling between the motor and load machine [5]. Therefore, in many cases the adoption of a model of the system as the two-mass system is more appropriate [11]. There are also drive systems where their modelling should take into account a larger number of masses and flexible connections, e.g. conveyors [6].

Issues related to the speed control of the two-mass system initially have been considered in the cases of rolling mills and other heavy industrial drive systems, where high inertia of the motors and long shafts have been cause of torsional vibrations excitation $[2,12,13]$. The development of microprocessor and power electronics technology enabling an effective electromagnetic torque control of the motors caused a visibility of the occurrence of torsional vibrations phenomena in other groups of drives, such as textiles, papers, radio telescopes, robots, cranes, servo drives and others $[1,3,4,7,13,15]$. In order to the damping of torsional vibrations are used, inter alia, mechanical vibration dampers. However, one of the most effective methods is an application of an appropriate control structure. There are many known speed control structures of the two-mass system, which review is presented in [5]. The simplest solutions are based on control structures using PI/PID controllers and basic feedback related to the speed of the motor. In more complex control structures are applied additional feedbacks related to an unmeasurable state variables of the drive system, such as the shaft torque, speed of the driven machine and load torque. In the case of the parameters variability, an adaptive or sliding mode control are applied. This ensures the proper operation of the control structure [13].

In industrial applications of the drive systems, the parameters variability have the greatest impact on their operation quality. In particular the change of value of the load machine time constant $T_{2}$. The occurrence of these factors causes the deterioration of the dynamic

(*) Tekst artykułu w polskiej wersji językowej dostępny w elektronicznym wydaniu kwartalnika na stronie www.ein.org.pl 
properties of the control structure and to change of assumed trajectory of the speed. In order to ensure the proper operation, the discussed adaptive control is applied [9]. Such type of control is also used in the control of different processes and objects where is parameters variability $[8,14]$.

The main goal of this paper is to present issues related to the application of a fuzzy Kalman filter in an adaptive control structure of the two-mass system with changeable inertia of the driven machine and the improvement of the estimation quality of the state variables and parameter of the considered drive system.

\section{Mathematical model of the plant and the control structure}

Object of the research is the drive system with elastic coupling which consists of concentrated masses of the motor and load machine deployed at the ends of the elastic shaft [10]. The commonly used inertia-free-shaft dual-mass system model has been applied [9]. This model is described by the following state equations (in per unit system):

$$
\frac{d}{d t}\left[\begin{array}{l}
\omega_{1}(t) \\
\omega_{2}(t) \\
m_{s}(t)
\end{array}\right]=\left[\begin{array}{ccc}
0 & 0 & \frac{-1}{T_{1}} \\
0 & 0 & \frac{-1}{T_{2}} \\
\frac{1}{T_{c}} & \frac{-1}{T_{c}} & 0
\end{array}\right]\left[\begin{array}{l}
\omega_{1}(t) \\
\omega_{2}(t) \\
m_{s}(t)
\end{array}\right]+\left[\begin{array}{c}
\frac{1}{T_{1}} \\
0 \\
0
\end{array}\right]\left[m_{e}\right]+\left[\begin{array}{c}
0 \\
\frac{-1}{T_{2}} \\
0
\end{array}\right]\left[m_{L}\right]
$$

where: $\omega_{1}-$ the motor speed, $\omega_{2}-$ the load machine speed, $m_{s}-$ the shaft torque, $m_{L}$ - the load torque, $T_{l}$ - the mechanical time constant of the motor, $T_{2}$ - the mechanical time constant of the load machine, $T_{c}$ - the stiffness time constant.

$$
G_{r}(s)=K_{p}+\frac{K_{i}}{s}
$$

where: $K_{i}, K_{p}$ - the integral and proportional gains of the speed controller.

The coefficients of the control structure have been selected on the basis of the current value of the load machine time constant $T_{2}$ according to the following formulas:

$$
\begin{gathered}
K_{i}=\omega_{r}^{4} T_{1} T_{2} T_{c} \\
K_{p}=4 \xi_{z} \omega_{r}^{3} T_{1} T_{2} T_{c} \\
k_{2}=\frac{1}{\omega_{r}^{3} T_{2} T_{c}}-1 \\
k_{1}=\frac{T_{1}\left(4 \xi_{z}^{2}-k_{2}\right)}{T_{2}\left(1+k_{2}\right)}-1 \\
k_{L 1}=T_{c} K_{I}\left(1+k_{2}\right)+1+k_{1}
\end{gathered}
$$

where: $\omega_{r}-$ the reference resonant pulsation, $\xi_{z}$ - the reference damping factor. The research have been carried out assuming the following values of the reference resonant pulsation and damping factor: $\omega_{r}=40 \mathrm{~s}^{-1}, \xi_{z}=0,7$.

\section{Mathematical model of the extended Kalman filter}

In the case of changeable values of the load machine time constant $T_{2}$, an extension of the state vector of the considered drive system by using of the parameter $T_{2}$ inverse and load torque $m_{L}$ is required. The assumption of the time constant inverse $1 / T_{2}$ is related to the simplification of calculations concerning linearization of the state equation. In this paper the wide range of changes of the time constant $T_{2}$ between $T_{2 N}$ and $4 T_{2 N}$ is assumed. After taking into account of these conditions the state vector takes the following form:

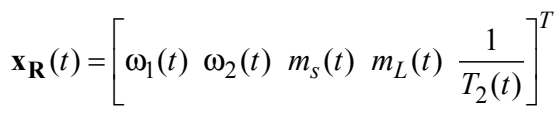

The extended state and output equations of the considered drive system can be formulated in the following form:

The adaptive control structure with PI controller and two additional feedbacks from the shaft torque $\left(k_{l}\right)$ and the speed difference $\left(k_{2}\right)$ has been applied in the research. Schematic diagram of the adaptive control structure is presented in the figure 1. It consists of the optimized electromagnetic control loop, mechanical part of the drive system, extended Kalman filter and PI controller.

The following transfer function of the electromagnetic torque control loop has been assumed:

$$
G_{t}(s)=\frac{1}{0,002 s+1}
$$

$$
\frac{d}{d t} \mathbf{x}_{\mathbf{R}}(t)=\mathbf{A}_{\mathbf{R}}\left(\frac{1}{T_{2}}(t)\right) \mathbf{x}_{\mathbf{R}}(t)+\mathbf{B}_{\mathbf{R}} \mathbf{u}(t)+\mathbf{w}(t)=\mathbf{f}_{\mathbf{R}}\left(\mathbf{x}_{\mathbf{R}}(t), \mathbf{u}(t)\right)+\mathbf{w}(t)
$$

$$
\mathbf{y}_{\mathbf{R}}(t)=\mathbf{C}_{\mathbf{R}} \mathbf{x}_{\mathbf{R}}(t)+\mathbf{v}(t)
$$

where: $\mathbf{w}(\mathrm{t}), \mathbf{v}(\mathrm{t})$ - white noises occurring in the system.

The matrices of the state, control and output are defined as follows:

The transfer function of the PI speed controller is presented below: 


$$
\mathbf{A}_{\mathbf{R}}\left(\frac{1}{T_{2}}(t)\right)=\left[\begin{array}{ccccc}
0 & 0 & \frac{-1}{T_{1}} & 0 & 0 \\
0 & 0 & \frac{1}{T_{2}(t)} & \frac{-1}{T_{2}(t)} & 0 \\
\frac{1}{T_{c}} & \frac{-1}{T_{c}} & 0 & 0 & 0 \\
0 & 0 & 0 & 0 & 0 \\
0 & 0 & 0 & 0 & 0
\end{array}\right], \mathbf{B}_{\mathbf{R}}=\left[\begin{array}{l}
\frac{1}{T_{1}} \\
0 \\
0 \\
0 \\
0
\end{array}\right], \mathbf{C}_{\mathbf{R}}=\left[\begin{array}{l}
1 \\
0 \\
0 \\
0 \\
0
\end{array}\right]^{T}
$$

The matrix $\mathbf{A}_{\mathbf{R}}$ depends on the parameter $T_{2}$. Assuming the parameter variation during operation of the drive system, an update of the matrix $\mathbf{A}_{\mathbf{R}}$ in every calculation step according to the current value of the estimated parameter of the load machine time constant $T_{2}$ is required. Input and output vectors of the drive system and Kalman filter are the electromagnetic torque and motor speed:

$$
\mathbf{u}=m_{e}, \mathbf{y}=\omega_{1}
$$

After discretization of the state equation (10) with a sampling pe$\operatorname{riod} T_{s}$, the estimation of the state variables process using the fuzzy Kalman filter is started. This algorithm can be described in the following steps:

\section{State prediction:}

$$
\hat{\mathbf{x}}_{\mathbf{R}}(k+1 / k)=\mathbf{A}_{\mathbf{R}}(k) \hat{\mathbf{x}}_{\mathbf{R}}(k / k)+\mathbf{B}_{\mathbf{R}} \mathbf{u}(k)
$$

\section{Covariance prediction:}

$$
\mathbf{P}(k+1 / k)=\mathbf{F}_{\mathbf{R}}(k) \mathbf{P}(k) \mathbf{F}_{\mathbf{R}}^{\mathbf{T}}(k)+\mathbf{Q}(k)
$$

where:

$$
\mathbf{F}_{\mathbf{R}}(k)=\left.\frac{\partial \mathbf{f}_{\mathbf{R}}\left(\mathbf{x}_{\mathbf{R}}(k / k) \mathbf{u}(k)\right)}{\partial \mathbf{x}_{\mathbf{p}}(k / k)}\right|_{\mathbf{x}_{\mathbf{R}}=\hat{\mathbf{x}}_{\mathbf{R}}(k / k)}
$$

$$
\mathbf{F}_{\mathbf{R}}=\left[\begin{array}{ccccc}
1 & 0 & \frac{-1}{T_{1}} T_{s} & 0 & 0 \\
0 & 1 & \frac{1}{T_{2}(k)} T_{s} & \frac{-1}{T_{2}(k)} T_{S} & T_{s}\left(m_{s}(k)-m_{L}(k)\right) \\
\frac{1}{T_{c}} T_{S} & \frac{-1}{T_{c}} T_{S} & 1 & 0 & 0 \\
0 & 0 & 0 & 1 & 0 \\
0 & 0 & 0 & 0 & 1
\end{array}\right]
$$

\section{Calculate of the Kalman gain:}

$\mathbf{K}(k+1)=\mathbf{P}(k+1 / k) \mathbf{C}_{\mathbf{R}}^{\mathbf{T}}(k+1)\left[\mathbf{C}_{\mathbf{R}}(k+1) \mathbf{P}(k+1 / k) \mathbf{C}_{\mathbf{R}}^{\mathbf{T}}(k+1)+\mathbf{R}(k)\right]^{-1}(17)$

\section{State update:}

$\hat{\mathbf{x}}_{\mathbf{R}}(k+1 / k+1)=\hat{\mathbf{x}}_{\mathbf{R}}(k / k)+\mathbf{K}(k+1)\left[\mathbf{y}(k+1)-\mathbf{C}_{\mathbf{R}}(k+1) \hat{\mathbf{x}}_{\mathbf{R}}(k+1 / k)\right](18)$
5. Covariance update:

$$
\mathbf{P}(k+1 / k+1)=\left[\mathbf{I}-\mathbf{K}(k+1) \mathbf{C}_{\mathbf{R}}(k+1)\right] \mathbf{P}(k+1 / k)
$$

6. Return to the first step.

This algorithm requires the selection of coefficients of the $\mathbf{Q}$ and $\mathbf{R}$ covariance matrices:

$$
\mathbf{Q}=\left[\begin{array}{ccccc}
q_{11} & 0 & 0 & 0 & 0 \\
0 & q_{22} & 0 & 0 & 0 \\
0 & 0 & q_{33} & 0 & 0 \\
0 & 0 & 0 & q_{44} & 0 \\
0 & 0 & 0 & 0 & q_{55}
\end{array}\right], \quad \mathbf{R}=[r]
$$

These values have been selected using a genetic algorithm according to assumed objective function:

$$
F_{1}=\frac{\left(\sum_{i=1}^{n}\left|\omega_{i 1}-\omega_{i 1 e}\right|\right) *\left(\sum_{i=1}^{n}\left|\omega_{i 2}-\omega_{i 2 e}\right|\right) *\left(\sum_{i=1}^{n}\left|m_{i s}-m_{i s e}\right|\right) *\left(\sum_{i=1}^{n}\left|m_{i L}-m_{i L e}\right|\right) *\left(\sum_{i=1}^{n}\left|T_{i 2}-T_{i 2 e}\right|\right)}{n}
$$

The above presented objective function takes into account all estimated variables included in the state vector of the considered drive system. Table 1 shows the obtained values of the coefficients of the matrices $\mathbf{Q}$ and $\mathbf{R}$.

Table 1. Values of the coefficients of the matrices $Q$ and $R$

\begin{tabular}{|c|c|c|c|c|c|}
\hline$q_{11}$ & $q_{22}$ & $q_{33}$ & $q_{44}$ & $q_{55}$ & $r$ \\
\hline 0,037 & 0,020 & $2 \mathrm{E}-5$ & 99,18 & 61,63 & 41,84 \\
\hline
\end{tabular}

\section{Applied fuzzy system}

In the paper the designed fuzzy system which introduces the adaptation of the selected coefficients of the Kalman filter covariance matrix $\mathbf{Q}$ is presented. The structure of this system is presented in the figure 2. The figure 3 shows the applied membership functions of input variables in the discussed fuzzy system. The calculation of the $q_{44}$ and $q_{55}$ coefficients values of the matrix $\mathbf{Q}$ is based on the current estimated value of the load machine time constant $T_{2 e}$ and the processed signal $S_{o}$ of the absolute value of difference between the electromagnetic and estimated shaft torques. The value of signal $S_{o}$ allows to distinguish the static and dynamic state of the considered drive system. In the case of the signal value exceeding the set limit, the fuzzy system retunes the coefficients of the covariance matrix on the values corresponding to the dynamic state of the drive system and specific value of the load machine time constant. Otherwise, the static state is recognized and the analogous retune process is carried out. The signal $S_{o}$ is the output of the input signal processing system, whose structure is shown in the figure 4 . In order to reduce the occurring high frequency disturbances, a low pass filter with a constant value of time constant $T_{f}$ has been applied in this system. In the research assumed $T_{f}=0,005 \mathrm{~s}$. The designed fuzzy system enables the shaping of a surface of the $\mathbf{Q}$ matrix coefficients $q_{44}$ and $q_{55}$ changes as a function of $T_{2 e}$ and $S_{o}$. The shape of the surface depends on the selected values of the coefficients $m_{i}$. In the present study, the selection has been carried out using the Pattern Search algorithm according to the following objective function: 


$$
F_{2}=\frac{\left(\sum_{i=1}^{n}\left|m_{i L}-m_{i L e}\right|\right) *\left(\sum_{i=1}^{n}\left|T_{i 2}-T_{i 2 e}\right|\right)}{n}
$$

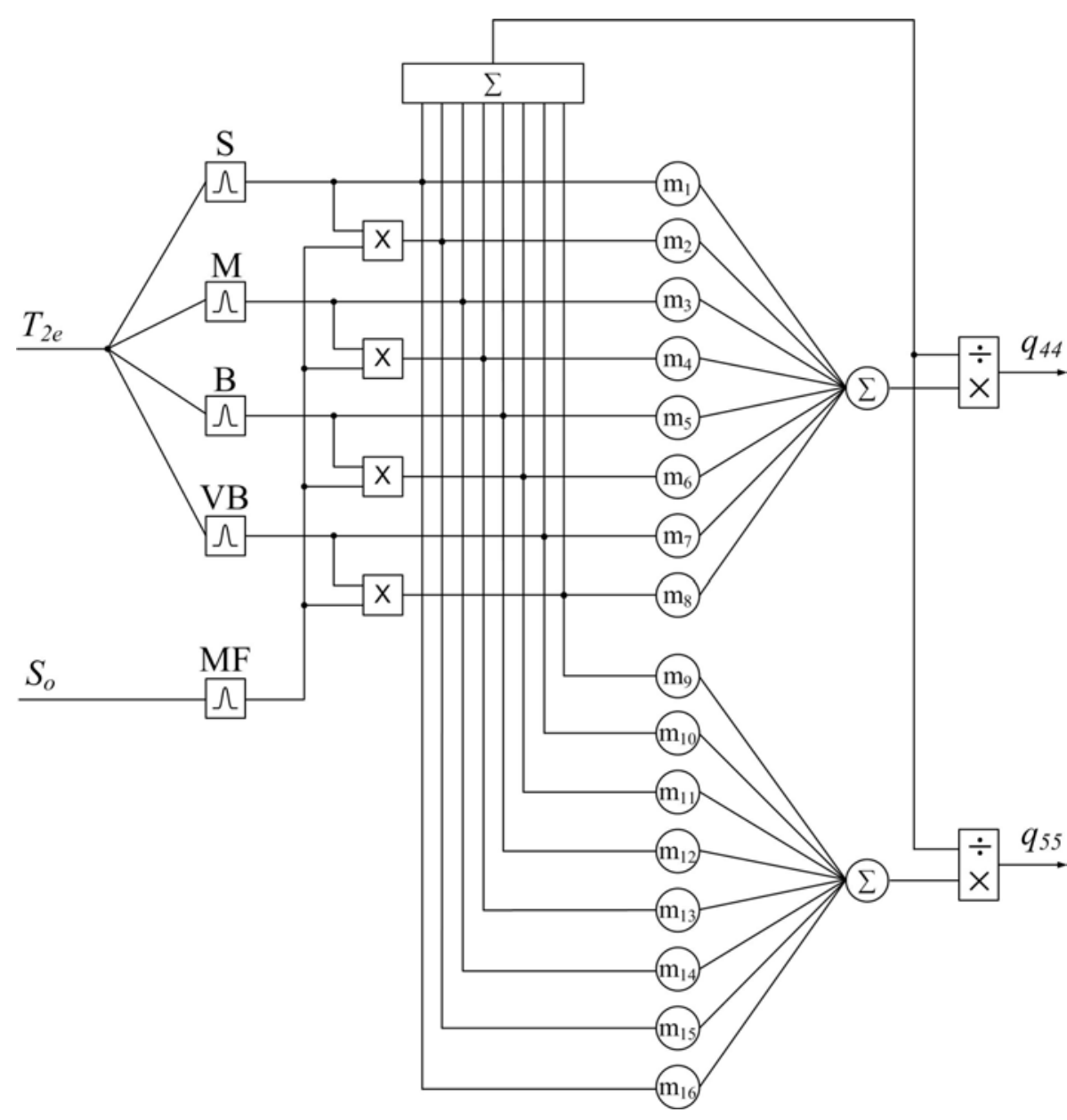

Fig. 2. Structure of the applied fuzzy system

a)

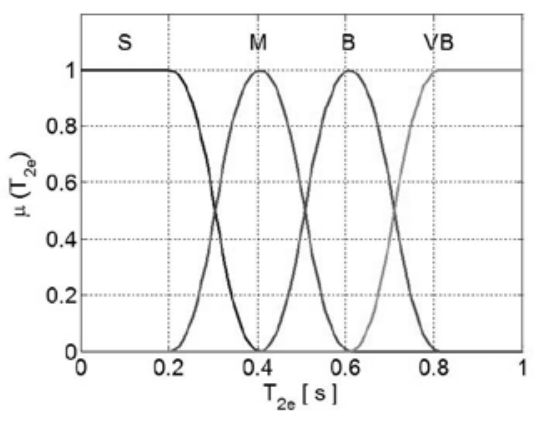

b)

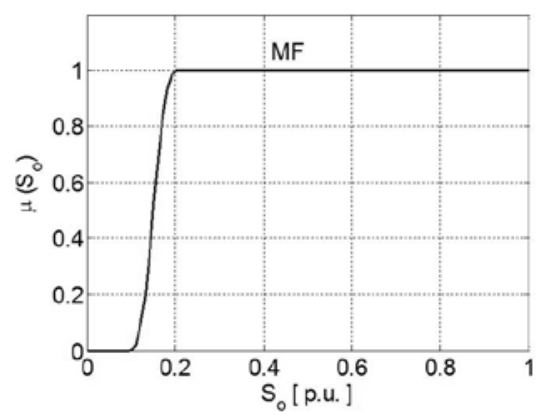

This process has been carried out in two steps because of the large number of parameters. First, the values of coefficients $m_{9}$ to $m_{16}$ have been optimized, keeping a constant value of the $q_{44}$. Next, the values of coefficients $m_{1}$ to $m_{8}$ have been optimized with variable $q_{55}$. In the both cases, the optimization algorithm starting points were the values of the Kalman filter covariance matrix coefficients $q_{44}$ and $q_{55}$. The obtained values of the individual coefficients $m_{i}$ are presented in the Table 2 .

\section{Selected results of the simulation research}

In the simulation research initially the extended Kalman filter with fixed coefficients of the $\mathbf{Q}$ and $\mathbf{R}$ matrices has been tested in the closed-loop control structure. Different operation conditions of the drive system than in the optimization process were assumed. A system to prevent simultaneous estimation of the load torque and the load machine time constant was applied. The figure 5 shows the selected results of this research. The changes of the load machine time constant during the operation of the drive system in the range of $T_{2 N}$ to $4 T_{2 N}$ were taken into account. The estimation quality of the motor speed, driven machine speed and shaft torque can be considered satisfactory. The analysis of the results showed that the control structure is working correctly. However, the transients of the estimated load torque and the load machine time constant are characterized by undesirable large estimation errors values that can be the cause of excitation of the torsional vibrations. In order to eliminate the discussed drawbacks, the adaptation of the coefficients $q_{44}$ and $q_{55}$ of the matrix $\mathbf{Q}$ using the designed fuzzy system has been applied. The figure 6 shows the selected results of the research of the closedloop control structure with the fuzzy Kalman filter. In order to evaluate the estimation quality and comparison of the both methods, the estimation errors of the individuals state variables and parameter have been calculated using following formula:

$$
\delta x=\frac{\sum_{i=1}^{n}\left|x_{i}-x_{i e}\right|}{n}, i=1, .2, . ., n
$$

where: $x$ - real value, $x_{e}$ - estimated value, $n-$ number of samples. The calculated values of the estimation errors are presented in the Table 3 . An analysis of the obtained results indicates the achievement of a significant improvement of the estimation quality of all estimated variables.

Fig. 3. Applied membership functions

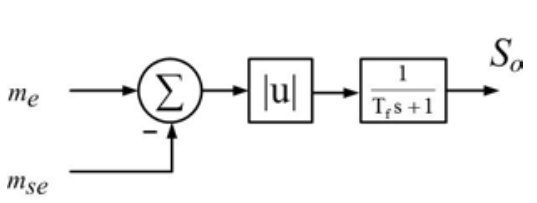

Fig. 4. Structure of the input signal processing system
Table 2. The obtained values of the individual coefficients $m_{i}$

\begin{tabular}{||c|c|c|c|c|c|c|c||}
\hline$m_{1}$ & $m_{2}$ & $m_{3}$ & $m_{4}$ & $m_{5}$ & $m_{6}$ & $m_{7}$ & $m_{8}$ \\
\hline 149,21 & 29,87 & 208,97 & $8,11 \mathrm{E}-4$ & 259,58 & 5,19 & 313,45 & 55,40 \\
\hline$m_{9}$ & $m_{10}$ & $m_{11}$ & $m_{12}$ & $m_{13}$ & $m_{14}$ & $m_{15}$ & $m_{16}$ \\
\hline 162,60 & 61426,94 & $7,34 \mathrm{E}-4$ & 3624,63 & 14,61 & 532,67 & 13,35 & 168,83 \\
\hline
\end{tabular}


a)

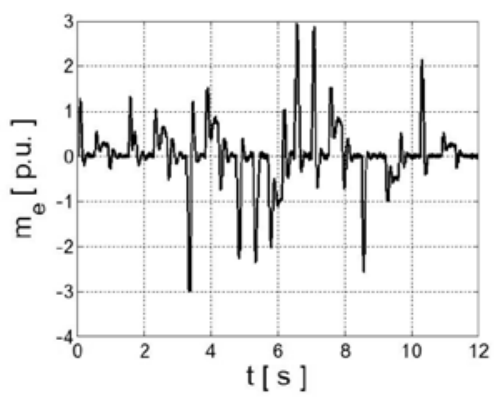

c)

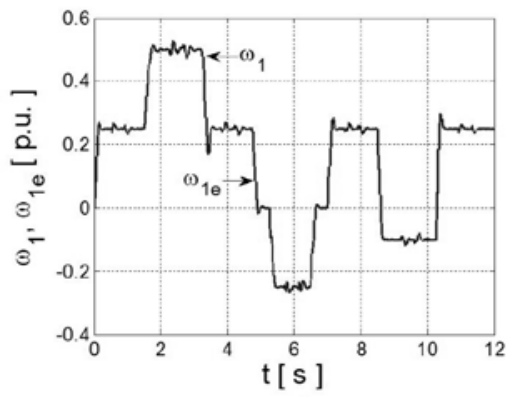

f)

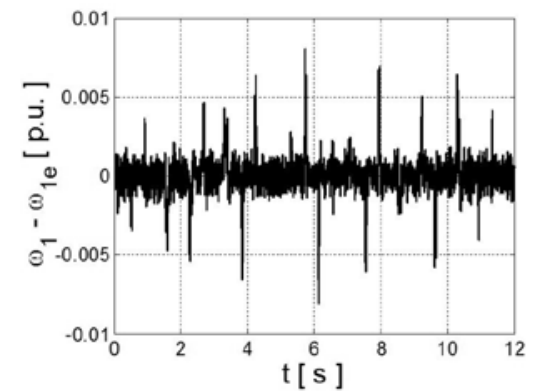

i)

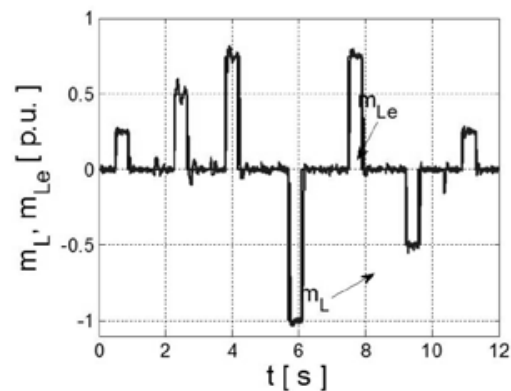

1)

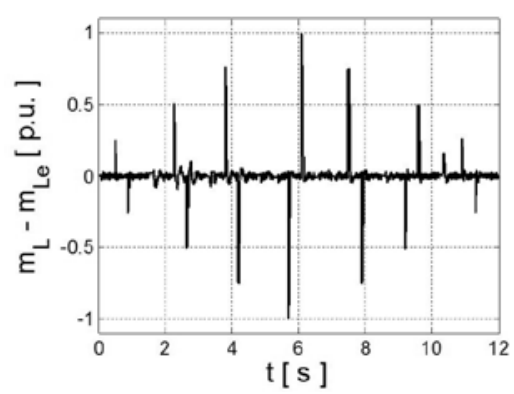

b)

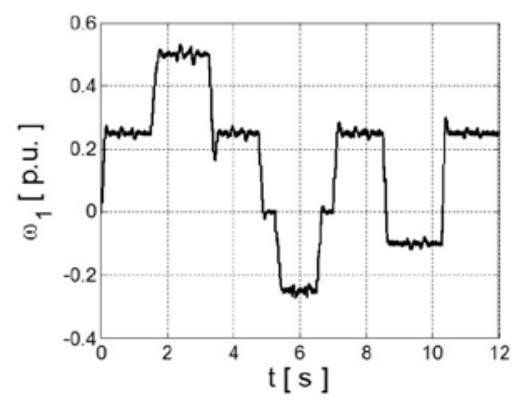

d)

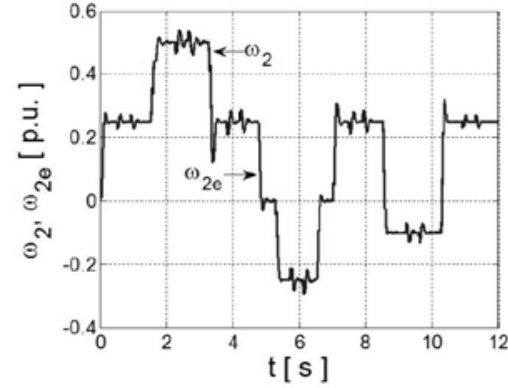

g)

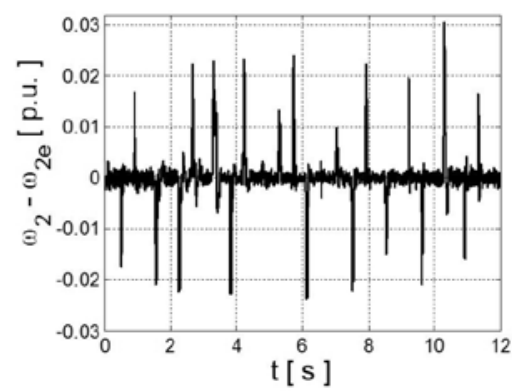

j)

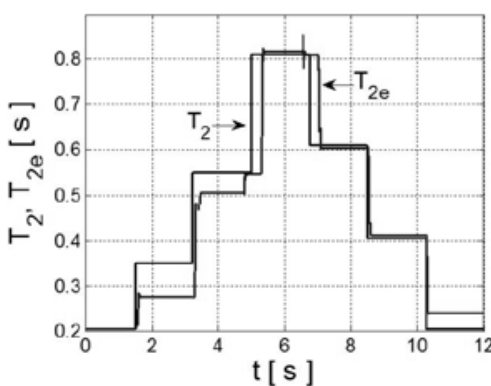

m)

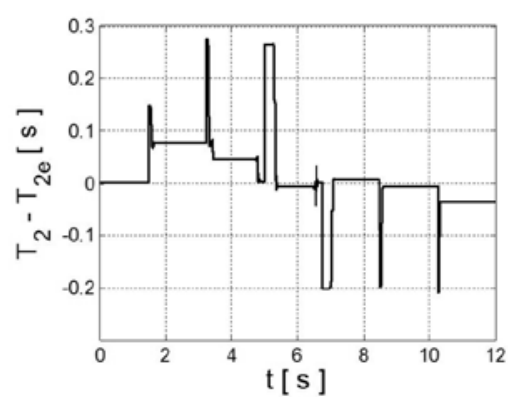

e)

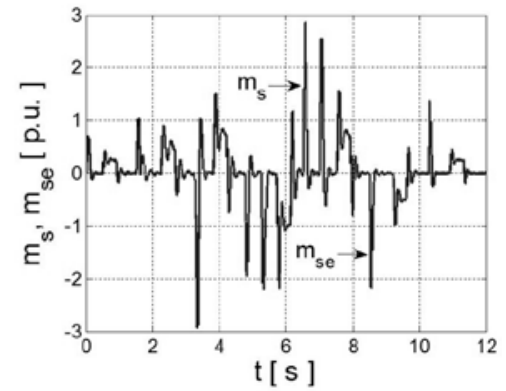

h)

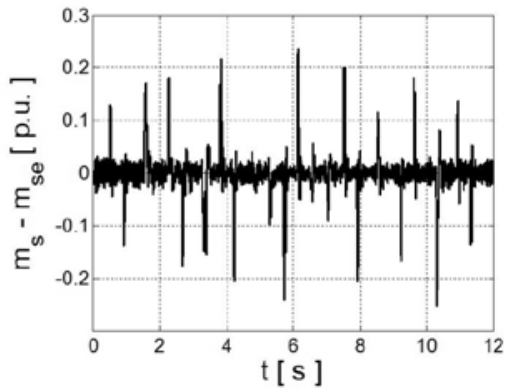

k)

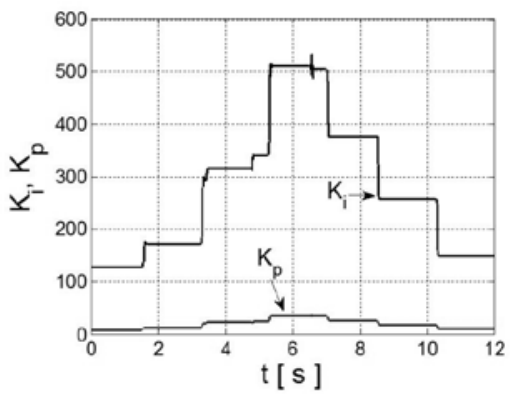

n)

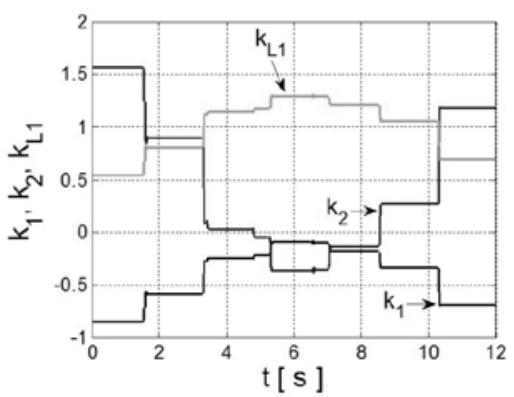

Fig. 5. Simulated transients of: the input signals of the extended Kalman filter - the electromagnetic torque (a) and the motor speed (b), the real and estimated variables and estimation errors of: the motor speed $(c, f)$, the load machine speed $(d, g)$, the shaft torque $(e, h)$, the load torque $(i, l)$, the time constant of the load machine $(j, m)$, the parameters of the control structure $(k, n)$ 
a)

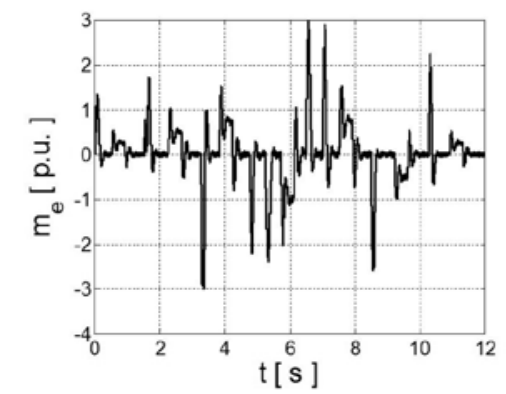

c)

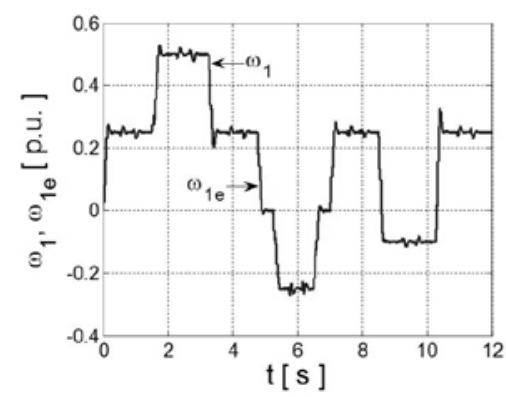

f)

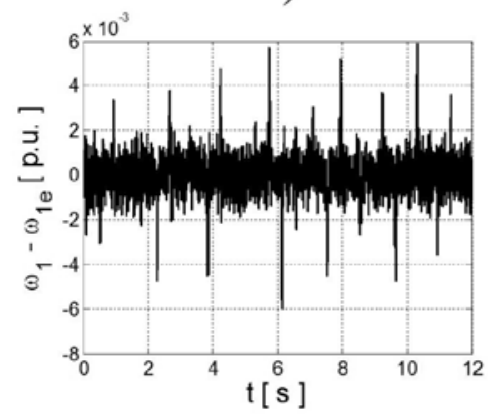

i)

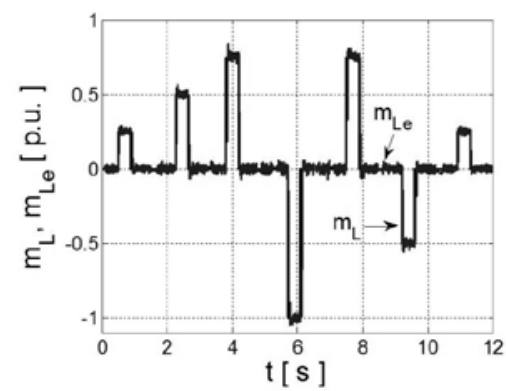

1)

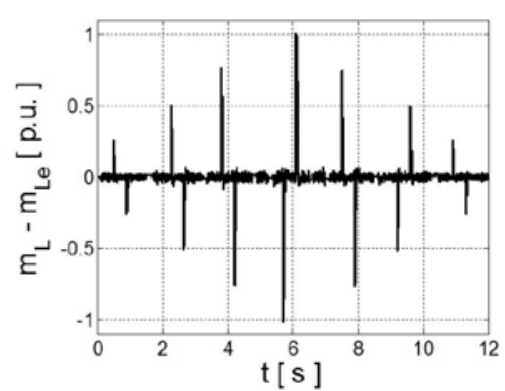

b)

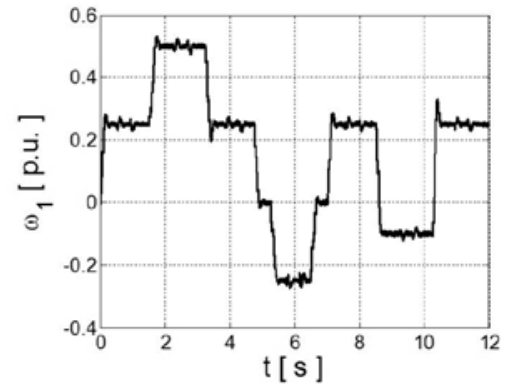

d)

e)

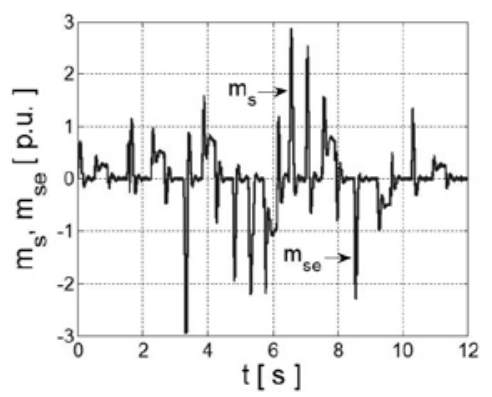

h)

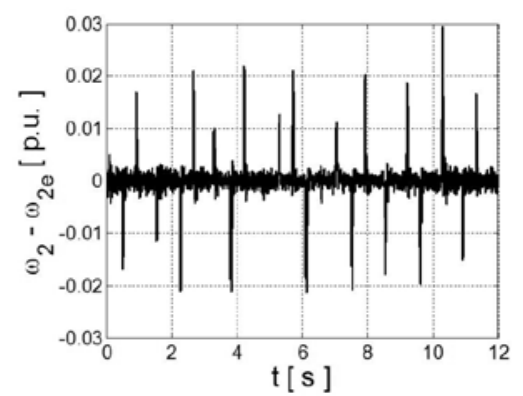

j)

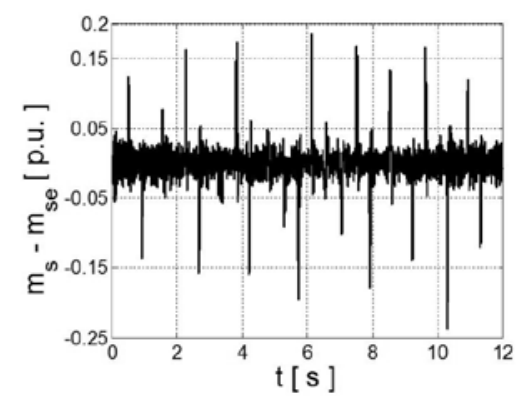

k)

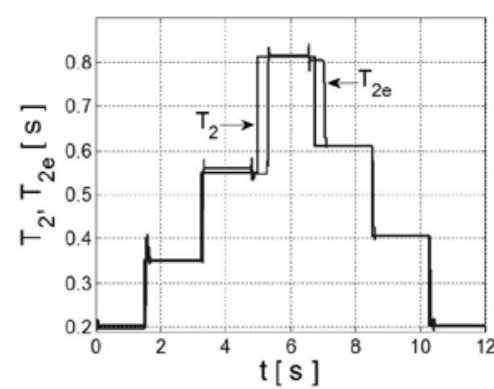

m)

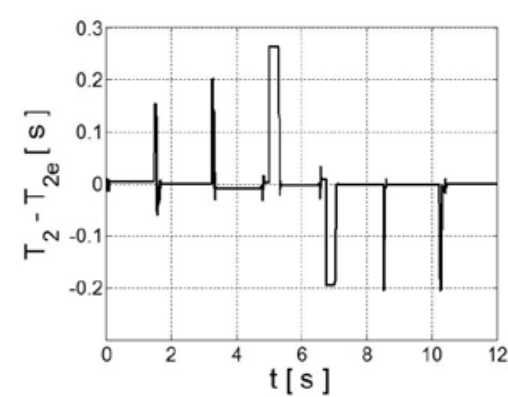

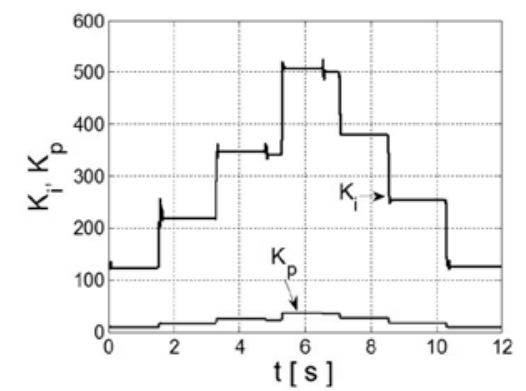

n)

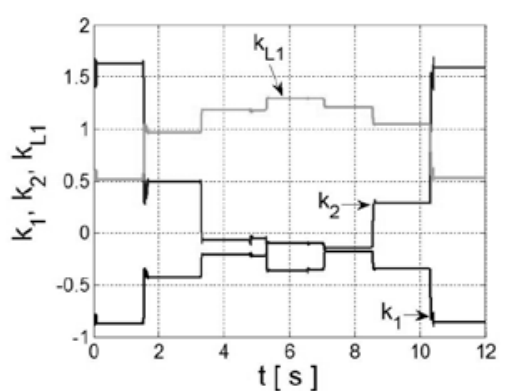

Fig. 6. Simulated transients of: the input signals of the fuzzy Kalman filter - the electromagnetic torque (a) and the motor speed (b), the real and estimated variables and estimation errors of: the motor speed $(c, f)$, the load machine speed $(d, g)$, the shaft torque (e, $h)$, the load torque $(i, l)$, the time constant of the load machine $(j, m)$, the parameters of the control structure $(k, n)$ 
a)

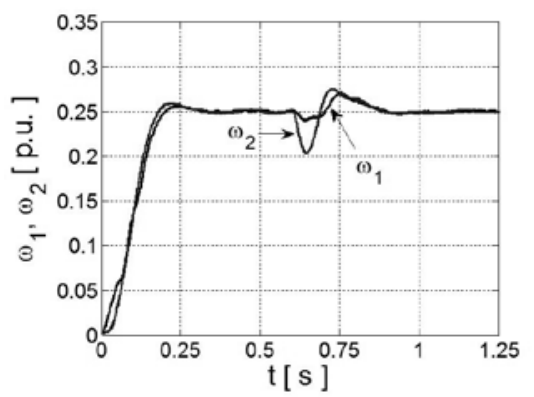

d)

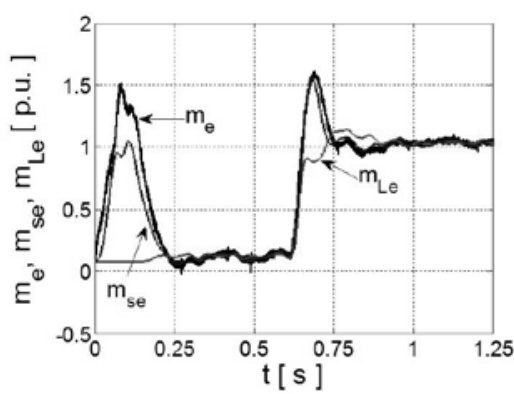

g)

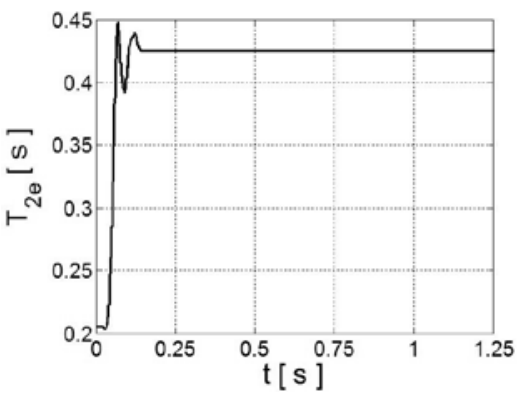

b)

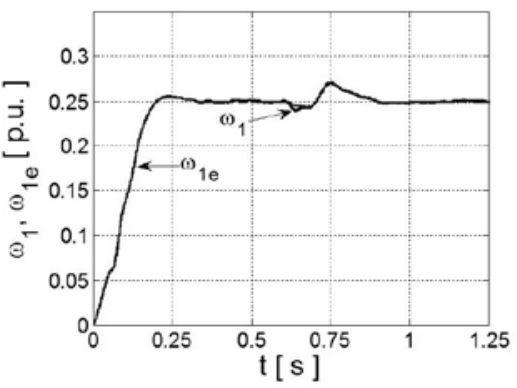

e)

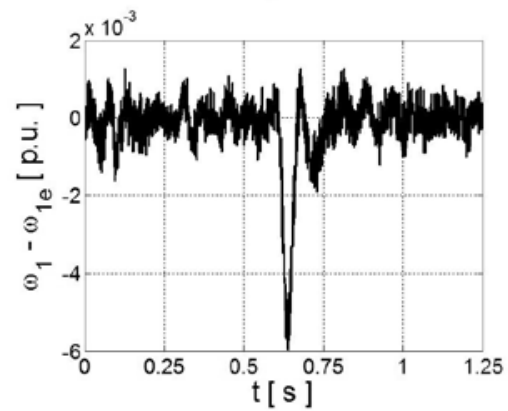

h)

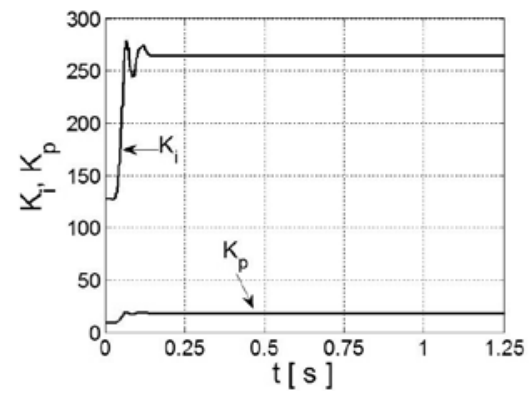

c)

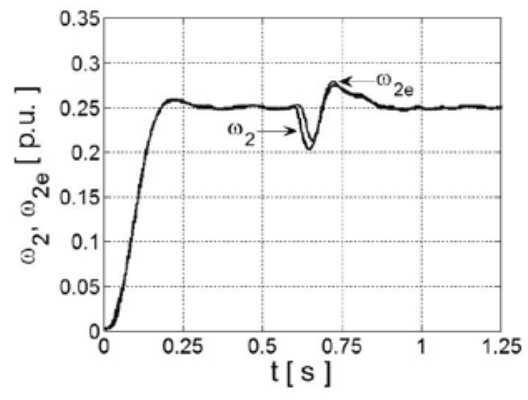

f)

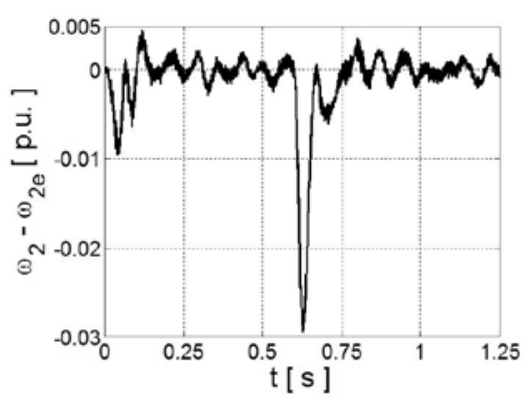

i)

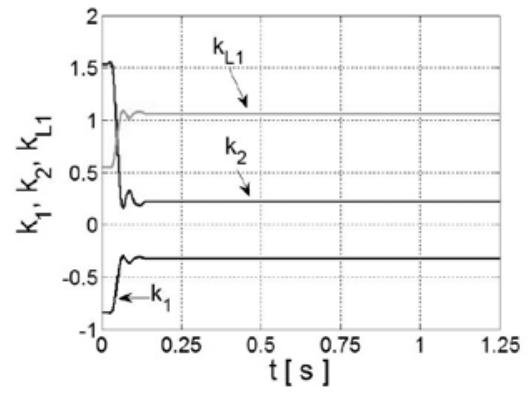

Fig. 7. Experimental transients of: the real and estimated motor speed (b) and load machine speed (c), the electromagnetic, shaft and load torques $(d)$, the estimation errors of the motor speed (e) and the load machine speed $(f)$, the parameters of the control structure $(f$, $g$ )

\section{Selected results of the experimental research}

In order to verify of the simulation research, the experimental tests of the proposed solution have been carried out on a laboratory set-up. This system consists of two $500 \mathrm{~W}$ DC machines connected by a long elastic shaft. The drive motor is fed by a H-bridge PWM converter. The load of the system has been carried out using a resistance modulator. The control algorithm has been implemented on the dSpace 1103 control platform. The speeds measurements have been realized through two incremental encoders (36000 impulses per rotation). The parameters of the electromagnetic control loop have been tuned in a way that ensures a fast control of this variable. The estimation of the unavailable state variables and parameter $T_{2}$ has been realized using the described fuzzy Kalman filter.

The adaptive control structure has been tested for the reference speed $\omega_{\text {ref }}=0,25 \omega_{N}$. This value was selected so as to avoid the electromagnetic torque limit. The results are presented in the figure 7. During the starting of the drive system the influence of the system to prevent simultaneous estimation of the load torque and the load machine time constant is visible. The control structure operation starts with the values of the coefficients $K_{i}, K_{p}, k_{1}, k_{2}, k_{L l}$ selected for incorrect value of the $T_{2 e}=0,203 \mathrm{~s}$. Then, at the time of starting the value of $T_{2 e}$ is calculated by the fuzzy Kalman filter algorithm and it tends to the real value of $T_{2}$ parameter. According to the equations (4)-(8) the coefficients of the control structure are retuned. Analysis of the results indicates the proper operation of the control structure.

\section{Conclusion}

In the paper issues related to the adaptive control of the two-mass system using the extended Kalaman filter are presented. The mathematical models of the considered drive system, Kalman filter and the control structure have been described. The designed fuzzy system, which task has been the adaptation of the $\mathbf{Q}$ covariance matrix coefficients $q_{44}$ and $q_{55}$, has been characterized. The selection way of the fuzzy system coefficients has been presented. The proposed fuzzy Kalman filter has been tested in the case of operation in the closed-loop control structure. The comparative research of the proposed algorithm with the classical extended Kalman filter have been carried out. The significant improvement of the all variables estimation quality has been obtained. The theoretical considerations and simulation studies have been verified in the experimental tests. Based on the extensive investigations, the following conclusions can be formulated:

- the application of the advanced adaptive control structure using the Kalman filters enables the effective damping of the torsional vibrations of the considered drive system with the elastic coupling, 
- the introducing of the designed fuzzy system to achieve the dynamic adaptation of the Kalman filter selected coefficients ensures the improvement of the all variables estimation quality in comparison to the classical algorithm. It has a positive impact on the operation of the control structure in the presence of changes of the time constant of the load machine in the wide range,

- the application of the Pattern Search algorithm to optimize the values of the fuzzy system singletons allows obtaining satisfactory results of the observer operation,

- using this algorithm should be pay particular attention to the appropriate form of the objective function.

\section{Acknowledgement}

This research work is supported by National Science Centre (Poland) under grant: Robust estimators of the system states and parameters for the drive system with an elastic joint - UMO-2011/01/B/ ST7/03500 (2011-2014).

\section{References}

1. Brock S, Deskur J, Janiszewski D, Muszyński R. Active damping of torsional vibrations in servodrives. Power Electronics and Electrical Drives. Selected Problems. Wrocław: Oficyna Wydawnicza Politechniki Wrocławskiej 2007: 278-297.

2. Butler D H E, Churches M A, Vergan E R, Anbe Y, Naitoh H. Compensation of a digitally controlled static power converter for the damping of rolling mill torsional vibration. IEEE Transactions on Industry Applications 1992; 28(2): 427-433, http://dx.doi.org/10.1109/28.126752.

3. De Luca A, Schroder D, Thummel M. An Acceleration-based State Observer for Robot Manipulators with Elastic Joints. IEEE International Conference on Robotics and Automation 2007: 3817-3823, http://dx.doi.org/10.1109/robot.2007.364064.

4. Gierlotka K. Układy sterowania napędów elektrycznych z elementami sprężystymi. Gliwice: Zeszyty Naukowe Politechniki Śląskiej 1992; 129(1181).

5. Kamiński M. Implementacja neuronowego estymatora prędkości napędu dwumasowego w układzie FPGA. Przegląd Elektrotechniczny 2010; 2: 225-230

6. Karolewski B, Ligocki P. Modelling of long belt conveyors. Eksploatacja i Niezawodnosc - Maintenance and Reliability 2014; 2: $179-187$.

7. Michael C A, Safacas A N. Dynamic and Vibration Analysis of a Multimotor DC Drive System With Elastic Shafts Driving a Tissue Paper Machine. IEEE Transactions on Industrial Electronics 2007; 54(4): 2033-2046, http://dx.doi.org/10.1109/TIE.2007.895149.

8. Poleszak J. The adaptive control of the injection timing in the diesel engine. Eksploatacja i Niezawodnosc - Maintenance and Reliability 2003; 2: 52-55.

9. Szabat K. Struktury sterowania elektrycznych układów napędowych z połączeniem sprężystym. Wrocław: Prace Naukowe Instytutu Maszyn, Napędów i Pomiarów Elektrycznych Politechniki Wrocławskiej 2008; 61(19).

10. Szabat K, Dybkowski M. Tłumienie drgań skrętnych w układzie dwumasowym z luzem mechanicznym. Przegląd Elektrotechniczny 2010; 2: $376-379$.

11. Szabat K, Orłowska-Kowalska T. Adaptive Control of Two-Mass System using Nonlinear Extended Kalman Filter. 32nd Annual Conference on IEEE Industrial Electronics IECON 2006: 1539-1544.

12. Szabat K, Orłowska-Kowalska T. Vibration Suppression in Two-Mass Drive System using PI Speed Controller and Additional Feedbacks Comparative Study. IEEE Transaction on Industrial Electronics 2007; 54(2): 1193-1206, http://dx.doi.org/10.1109/TIE.2007.892608.

13. Szabat K, Serkies P J. Zastosowanie sterowania predykcyjnego w układzie napędowym z połączeniem sprężystym. Przegląd Elektrotechniczny 2010; $2: 380-383$.

14. Świć A, Taranenko W. Adaptive control of machining accuracy of axial-symmetrical low-rigidity parts in elastic-deformable state. Eksploatacja i Niezawodnosc - Maintenance and Reliability 2012; 3: 17-25.

15. Zoller T, Leibfried T, Miri A M. Application of Power Electronics for Damping of Torsional Vibrations. 7th International Conference on Power Electronics and Drive Systems PEDS 2007: 521-525, http://dx.doi.org/10.1109/peds.2007.4487750.

\section{Krzysztof DRÓżDż}

Wrocław University of Technology

Faculty of Electrical Engineering

Department of Electrical Machines, Drives and Measurements

Wybrzeże Wyspiańskiego 27, 50-370 Wrocław, Poland

E-mail: krzysztof.drozdz@pwr.edu.pl 